IQTISHODUNA

Vol. 16 (1), 2020

P-ISSN: 1829-524X, E-ISSN: 2614-3437

\title{
Pengaruh Profitabilitas, Tingkat Pertumbuhan Aktiva, Leverage Operasi, Stabilitas Penjualan terhadap Struktur Modal dan Nilai Perusahaan
}

\author{
Kety Lulu Agustin ${ }^{*}$, Ubud Salim², Andarwati ${ }^{3}$ \\ 1,2,3Fakultas Ekonomi Universitas Brawijaya Malang, Indonesia
}

$\Xi$ Corresponding Author:

Nama Penulis: Kety Lulu Agustin

E-mail: Ketylulu78@yahoo.com

\begin{abstract}
The purpose of this research is to determine the effect of profitability, asset growth, operating leverage and sales stability on the capital structure and firm value. The company value in this study was published with Tobin $Q$. The population of this study were all manufacturing companies reported on the Indonesia Stock Exchange for the period 2015-2017. In accordance with the selection criteria, there are 46 filtered sample companies. The analysis technique that used is Partial Least Square (PLS). The results of hypothesis indicate profitability and sales that are significant to the capital structure while increasing performance and leverage of operations do not have a significant effect on capital structure. Profitability, asset growth, sales stability have a significant effect on firm value while operating leverage does not involve significance to firm value. Profitability and influence of sales have a significant effect on firm value through capital structure, while yield growth and operating leverage are opposite.
\end{abstract}

Keywords: Profitability, Asset Growth, Operating Leverage, Sales Stability, Capital Structure, Firm Value.

\begin{abstract}
Abstrak: Tujuan dari penelitian ini adalah untuk mengetahui pengaruh profitabilitas, pertumbuhan aset, leverage operasi dan stabilitas penjualan terhadap struktur modal dan nilai perusahaan. Nilai perusahaan dalam penelitian ini dihitung menggunakan Tobin's Q. Populasi penelitian ini adalah semua perusahaan manufaktur yang dilaporkan di Bursa Efek Indonesia untuk periode 2015-2017. Sesuai dengan kriteria pemilihan sampel, ada 46 perusahaan sampel yang tersaring. Teknik analisis yang digunakan adalah Partial Least Square (PLS). Hasil pengujian hipotesis dengan menggunakan menunjukkan bahwa profitabilitas dan stabilitas penjualan yang signifikan terhadap struktur modal sementara tingkat pertumbuhan aktiva dan leverage operasi tidak memiliki pengaruh signifikan terhadap struktur modal. Profitabilitas, tingkat pertumbuhan aktiva, stabilitas penjualan berpengaruh signifikan terhadap nilai perusahaan sedangkan leverage operasi tidak signifikan dengan nilai perusahaan. Profitabilitas dan stabilitas penjualan berpengaruh signifikan terhadap nilai perusahaan melalui struktur modal, sementara tingkat pertumbuhan aktiva dan leverage operasi sebaliknya.
\end{abstract}

Kata kunci: Profitabilitas, Tingkat Pertumbuhan Aktiva, Leverage Operasi, Stabilitas Penjualan, Struktur Modal, Nilai Perusahaan. 
| Draft awal Juni 2019 |Diterima Februari 2020 | Terbit April 2020 |

| DOI: http://dx.doi.org/10.18860/iq.v16i1.7276

\section{Cara mencitasi:}

Agustin, K.L., Salim, U., Andarwati. (2020). Pengaruh Profitabilitas, Tingkat Pertumbuhan Aktiva, Leverage Operasi, Stabilitas Penjualan terhadap Struktur Modal dan Nilai Perusahaan. Iqtishoduna. Vol. 16 (1): pp 17-38.

\section{Pendahuluan}

Pada masa pembangunan saat ini, persaingan di dunia usaha terutama di industri manufaktur semakin meningkat. Hal tersebut membuat setiap perusahaan manufaktur semakin meningkatkan kinerja agar tujuannya dapat tetap tercapai. Salah satu tujuan perusahaan adalah untuk memaksimumkan kemakmuran pemegang saham melalui memaksimalkan nilai perusahaan (Sartono, 2010). Bagi perusahaan publik, nilai perusahaan tercermin dari harga sahamnya. Semakin tinggi harga saham, semakin tinggi pula nilai perusahaan tersebut (Husnan, 2008). Untuk meningkatkan harga sahamnya, perusahaan harus dapat memberikan sinyal yang baik untuk menciptakan reaksi positif dari pasar. Salah satu upaya yang dilakukan oleh perusahaan adalah dengan mengoptimalkan struktur modalnya dan meminimalkan risiko sehingga direspon positif oleh investor.

Kebijakan hutang merupakan instrumen yang sangat sensitif terhadap nilai perusahaan. Semakin tinggi proporsi hutang, maka semakin tinggi harga saham, namun pada titik tertentu peningkatan hutang akan menurunkan nilai perusahaan karena manfaat yang diperoleh dari penggunaan hutang lebih kecil daripada biaya yang ditimbulkannya. Para pemilik perusahaan lebih suka jika perusahaan menciptakan hutang pada tingkat tertentu untuk menaikkan nilai perusahaan (Nuraina, 2012).

Untuk tetap bisa bersaing dan bertahan, perusahaan harus bisa lebih unggul dari pesaing-pesaingnya. Salah satu sektor pendukung untuk kelangsungan suatu industri adalah ketersediaan dana. Suatu perusahaan tidak hanya dituntut untuk menghasilkan suatu produk yang bermutu, tetapi juga harus mampu mengelola keuangan dengan baik. Setiap manajer keuangan sebuah perusahaan diharapkan dapat membuat keputusan investasi yang baik dan keputusan pendanaan yang baik, karena untuk mengetahui perimbangan struktur modal yang optimal bagi perusahaan dapat dilakukan dengan menyusun anggaran pendanaan sebaik mungkin.

18| IQTISHODUNA Vol. 16 (1), 2020

http://ejournal.uin-malang.ac.id/index.php/ekonomi 
Struktur modal baru dapat dikatakan optimal jika adanya kombinasi antara hutang dan modal yang berfungsi untuk memaksimumkan harga saham perusahaan (Brigham dan Houston, 2001). Berdasarkan pada prinsip hati-hati, maka berdasarkan pada aturan struktur finansial yang konservatif dalam mencari struktur modal yang optimal, yang artinya perusahaan tidak boleh mempunyai jumlah hutang yang lebih besar daripada jumlah modal sendiri. Sumber pendanaan dapat diperoleh dari dalam perusahaan (internal financing), seperti laba ditahan atau cadangan dana yang dimiliki perusahaan. Di samping itu, dana juga bisa diperoleh dari luar perusahaan (eksternal financing), seperti hutang (Niztiar, 2013). Apabila jumlah hutang sudah melebihi jumlah ekuitas yang dimiliki oleh perusahaan, maka risiko perusahaan dari sisi likuiditas akan semakin tinggi.

Permasalahan struktur modal seringkali dialami oleh banyak perusahaan terkait pilihan sumber dana apa yang harus dipilih oleh manajer, baik mengeluarkan saham baru atau hutang. Ermad (2012) mengatakan bahwa seberapa besar hutang atau mengeluarkan saham baru adalah hal penting yang perlu diperhatikan oleh manajer perusahaan. Pada saat ini dunia usaha tergantung pada masalah pendanaan, dunia usaha mengalami kemunduran yang diakibatkan dari banyaknya lembaga-lembaga keuangan yang mengalami kesulitan keuangan sebagai adanya kemacetan kredit pada dunia usaha tanpa memperhitungkan batas maksimum pemberian kredit dimasa lalu oleh perbankan dan masalah kelayakan kredit yang disetujui (Safrida, 2008). Oleh karena itu, manajer keuangan diharapkan dapat mengantisipasi kondisi tersebut dengan berhati-hati dalam menetapkan struktur modal perusahaan sehingga dapat meningkatkan nilai perusahaan.

Keputusan struktur modal yang tidak tepat juga akan menimbulkan biaya modal tinggi sehingga berdampak pada penurunan atau rendahnya laba yang dihasilkan perusahaan. Keputusan struktur modal sangat mempengaruhi kondisi keuangan yang tentunya akan berdampak pada nilai perusahaan. Oleh sebab itu, penting bagi perusahaan untuk mengetahui faktor-faktor yang mempengaruhi struktur modal. Faktor-faktor yang mempengaruhi struktur modal perusahaan sudah menjadi pembahasan selama beberapa periode. Salah satu faktor yang menentukan struktur modal perusahaan adalah profitabilitas. Profitabilitas mengukur kemampuan perusahaan dalam menghasilkan laba. Perusahaan yang mengalami kesulitan keuangan lebih banyak memerlukan pinjaman atau mengeluarkan saham baru untuk dapat mendanai kegiatan operasionalnya. Perusahaan dengan kondisi keuangan yang baik memerlukan pinjaman yang lebih sedikit walaupun mempunyai kesempatan meminjam lebih banyak (Chen dan 
Hemmes dalam Seftianne dan Handayani, 2011).

Tingkat pertumbuhan aktiva juga merupakan salah satu faktor yang mempengaruhi struktur modal. Perusahaan dengan prospek pertumbuhan besar harus menyediakan modal yang dapat mencukupi semua biaya yang keluar dari operasional perusahaan. Perusahaan yang tumbuh dengan cepat lebih mengandalakan diri pada modal eksternal. Sedangkan, perusahaan dengan prospek pertumbuhan kecil menggunakan lebih banyak utang karena perusahaan tersebut akan membutuhkan dana yang besar untuk tumbuh dan mengembangkan usahanya yang tidak dapat dipenuhi semuanya melalui modal sendiri (Brigham dan Houston, 2006).

Perusahaan dengan operating leverage yang lebih sedikit memiliki kemampuan yang lebih baik dalam menerapkan leverage keuangan karena perusahaan tersebut akan memiliki operating leverage yang kecil (Brigham dan Houston, 2006). Sedangkan perusahaan yang mempunyai operating leverage yang tinggi, cenderung untuk mengurangi struktur modal guna memperkecil beban yang harus dikeluarkan. Semakin besar beban tetap, maka semakin kecil keuntungan yang didapat (Wulandari, 2013).

Stabilitas penjualan juga merupakan salah satu faktor yang sangat berpengaruh terhadap struktur modal. Menurut Wetson dan Copeland (2008) stabilitas penjualan dan rasio hutang berkaitan erat sekali. Bila stabilitas penjualan dan laba lebih besar, maka beban tetap yang terjadi pada suatu perusahaan akan mempunyai risiko yang lebih kecil dibandingkan dengan perusahaan yang penjualan dan labanya menurun tajam. Bila laba kecil, maka perusahaan akan menemui kesulitan untuk membayar bunga tetap dari obligasi begitupun sebaliknya. Tujuan penelitian adalah untuk mengetahui sejauh mana peranan variabel profitabilitas, tingkat pertumbuhan aktiva, leverage operasi dan stabilitas penjualan berpengaruh terhadap struktur modal dan juga terhadap nilai perusahaan pada perusahaan manufaktur yang terdaftar di Bursa Efek Indonesia pada tahun 2015 sampai dengan 2017.

\section{Kajian Pustaka \\ Profitabilitas}

Menurut Munawir (2007), profitabilitas adalah kemampuan perusahaan untuk menghasilkan laba. Sedangkan menurut Sudana (2011) Profitabilitas adalah kemampuan perusahaan untuk menghasilkan laba dengan menggunakan sumber-sumber yang dimiliki seperti aktiva, modal atau penjualan perusahaan. Dari definisi-definisi di atas, dapat disimpulkan bahwa rasio profitabilitas (profitability ratio) adalah rasio atau perbandingan yang digunakan untuk mengetahui kemampuan perusahaan untuk

20| IQTISHODUNA Vol. 16 (1), 2020 http://ejournal.uin-malang.ac.id/index.php/ekonomi 
mendapatkan laba (profit) dari pendapatan (earning) yang diperoleh oleh perusahaan. Dalam penelitian ini profitabilitas diukur dengan menggunakan rasio return on equity ( $R O E$ ).

\section{Pertumbuhan Aktiva}

Brigham dan Houston (2001), mendefinisikan tingkat pertumbuhan aktiva sebagai perubahan aset tahunan dari total aktiva. Hal ini dapat dibuktikan melalui perusahaan yang tumbuh dapat dilihat dari peningkatan aktiva untuk memperbesar ukuran perusahaan. Konsep ini didasarkan pada dua argumentasi yaitu pertama, pertumbuhan aktiva berbeda dengan pertumbuhan penjualan yang setiap usaha yang dilakukan secara langsung membawa implikasi pada penerimaan. pertumbuhan aktiva mencerminkan waktu yang lebih panjang dari pertumbuhan penjualan. Kedua, investasi pada aktiva membutuhkan waktu sebelum dioperasikan, sehingga aktifitas yang dilakukan tidak terkait dengan penerimaan.

\section{operating leverage}

Keown dan David (2000) mengemukakan pengertian operating leverage adalah pembiayaan tetap perusahaan di dalam arus pendapatan perusahaan. Operating leverage muncul pada saat perusahaan menggunakan aktiva yang memiliki biaya-biaya operasi tetap, misalnya biaya penyusutan gedung dan peralatan kantor, biaya asuransi dan biaya lainnya yang muncul akibat penggunaan fasilitas dan biaya manajemen. Menurut Sjahrial (2009), leverage adalah penggunaan aktiva dan sumber dana oleh perusahaan yang memiliki biaya tetap (beban tetap) berarti sumber dana yang berasal dari pinjaman karena memiliki bunga sebagai beban tetap dengan maksud agar meningkatkan keuntungan potensial pemegang saham.

\section{Stabilitas Penjualan}

Menurut Rudianto (2009) menyatakan bahwa pertumbuhan penjualan merupakan volume penjualan pada tahun-tahun mendatang, berdasarkan data pertumbuhan volume penjualan historis. Pertumbuhan penjualan merupakan perubahan kenaikan ataupun penurunan penjualan dari tahun ke tahun yang dapat dilihat pada laporan laba-rugi perusahaan. Perusahaan yang baik bisa dilihat dari penjualannya dari tahun ke tahun yang terus mengalami peningkatan, hal tersebut berimbas pada meningkatnya keuntungan perusahaan sehingga pendanaan internal perusahaan juga meningkat.

\section{Struktur Modal}

Menurut Riyanto dalam Hermuningsih (2013) merupakan bagian dari struktur keuangan yang mencerminkan perimbangan (absolut maupun relatif) antara keseluruhan modal eksternal (baik jangka pendek maupun 
jangka panjang) dengan jumlah modal sendiri. Sedangkan menurut Husnan (2009) struktur modal adalah perbandingan antara modal asing (dari luar) dengan modal sendiri. Dari beberapa definisi yang telah dikemukakan oleh para ahli, dapat disimpulkan bahwa struktur modal merupakan gabungan sumber dana perusahaan yaitu hutang, saham dan modal sendiri yang digunakan untuk pemenuhan kebutuhan belanja perusahaan.

\section{The Modigliani-Miller Model}

Modigliani dan Miller (1958) berpendapat bahwa dengan asumsi perfect capital market, struktur modal yang digunakan perusahaan tidak mempengaruhi nilai perusahaan. Tetapi jika ada pajak maka perusahaan akan menggunakan utang lebih banyak sehingga nilai perusahaan menjadi meningkat.

\section{Pecking Order Theory}

Teori pecking order menyatakan bahwa perusahaan cenderung mencari sumber pendanaan yang minim risiko. Teori pecking order lebih menyukai pendanaan dari internal perusahaan daripada eksternal perusahaan. Menurut Brealey, Myers dan Marcus (2008) teori pecking order menyatakan bahwa perusahaan lebih suka menerbitkan utang dibandingkan ekuitas jika dana internal tidak cukup.

\section{Nilai Perusahaan}

Menurut Sudana (2011) menyatakan bahwa nilai perusahaan merupakan nilai sekarang dari arus kas pendapatan atau kas yang diharapkan akan diterima pada masa yang akan datang. Menurut Sartono (2010), nilai perusahaan adalah nilai jual sebuah perusahaan sebagai suatu bisnis yang sedang beroperasi. Berdasarkan beberapa definisi di atas, dapat disimpulkan bahwa nilai perusahaan merupakan nilai yang diharapkan akan diperoleh oleh para investor pada masa yang akan datang.

\section{Model Hipotesis}

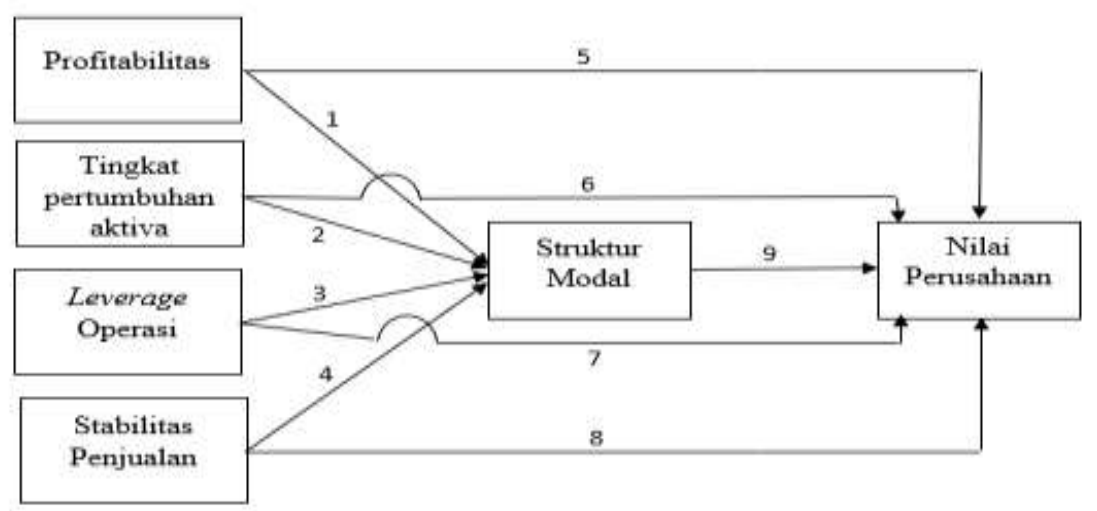

Gambar 1. Model Hipotesis

22 | IQTISHODUNA Vol. 16 (1), 2020

http://ejournal.uin-malang.ac.id/index.php/ekonomi 


\section{Hipotesis Penelitian :}

H.1 : Semakin tinggi Profitabilitas akan menurunkan struktur modal.

H.2 : Semakin tinggi tingkat pertumbuhan aktiva akan menurunkan struktur modal.

H.3 : Semakin besar operating leverage akan menurunkan struktur modal.

H.4: Semakin tinggi stabilitas penjualan akan meningkatkan struktur modal.

H.5 : Semakin tinggi profitabilitas akan meningkatkan nilai perusahaan.

H.6 : Semakin tinggi tingkat pertumbuhan aktiva akan meningkatkan nilai perusahaan.

H.7 : Semakin besar operating leverage akan menurunkan nilai perusahaan.

H.8: Semakin tinggi stabilitas penjualan akan meningkatkan nilai perusahaan

H.9 : Semakin rendah struktur modal akan meningkatkan nilai perusahaan.

H.10 : Semakin tinggi profitabilitas akan meningkatkan nilai perusahaan melalui struktur modal

H.11 : Semakin tinggi tingkat pertumbuhan aktiva akan meningkatkan nilai perusahaan melalui struktur modal

H.12 : Semakin besar operating leverage akan menurunkan nilai perusahaan melalui struktur modal.

H.13 : Semakin tinggi stabilitas penjualan akan meningkatkan nilai perusahaan melalui struktur modal.

\section{Metodologi Penelitian}

Penelitian ini dilakukan dalam rangka upaya menemukan, mengkaji, serta mengkonfirmasi teori dalam suatu pengetahuan. Berdasarkan tujuan yang hendak dicapai, maka penelitian ini merupakan penelitian explanatory dengan menggunakan pendekatan kuantitatif. Populasi dalam penelitian ini adalah seluruh perusahaan manufaktur yang terdaftar di BEI pada periode tahun 2015 sampai dengan 2017 yang berjumlah 137 perusahaan manufaktur. Populasi dalam penelitian ini memiliki beberapa kriteria populasi, yaitu: (1) perusahaan manufaktur yang terdaftar di Bursa Efek Indonesia; (2) perusahaan manufaktur yang tidak di delisting atau di relisting selama periode penelitian; (3) perusahaan manufaktur yang menyajikan laporan keuangan dalam satuan mata uang rupiah selama periode penelitian (4) perusahaan manufaktur yang memiliki nilai laba positif selama periode penelitian; dan (5) perusahaan manufaktur yang memiliki nilai pertumbuhan aktiva yang positif pada periode penelitian tahun 2015-2017. Teknik sampling yang digunakan dalam penelitian ini adalah sampel jenuh atau sensus, dikarenakan secara keseluruhan jumlah populasi yang memenuhi kriteria sampel digunakan sebagai sampel penelitian. Dari kriteria diatas terdapat 46 perusahaan yang memenuhi kriteria dan digunakan dalam penelitian ini. 
Sumber data dalam penelitian ini adalah data sekunder, yakni data yang diperoleh peneliti secara tidak langsung melalui media perantara (diperoleh dan dicatat oleh pihak lain). Data diperoleh melalui website resmi Bursa Efek Indonesia. Data yang digunakan berupa data-data laporan tahunan selama periode observasi penelitian dari tahun 2016-2017. Teknik pengumpulan data dalam penelitian adalah teknik dokumentasi.

Metode analisis data yang digunakan dalam penelitian ini adalah Analisis Statistik Deskriptif dan Partial Least Square (PLS). Software PLS pada penelitian ini menggunakan software yang dikembangkan di University of Hamburg Jerman yang diberi nama SMARTPLS versi 2.0 M3. Dalam PLS memerlukan 2 tahap untuk menilai Fit Model dari sebuah model penelitian, yaitu menilai Outer Model atau Measurement Model dan Model Struktural (Inner Model).

\section{Hasil Penelitian}

H.1 : Semakin tinggi Profitabilitas akan menurunkan struktur modal.

Hasil pengujian hipotesis pertama menunjukkan bahwa hubungan variabel profitabilitas (X1) dengan struktur modal (Y1) menunjukkan nilai koefisien jalur sebesar -0,269 dengan nilai t sebesar 2,498. Nilai t hitung tersebut lebih besar dari t tabel $(1,960)$. Hasil ini berarti bahwa profitabilitas memiliki pengaruh yang negatif dan signifikan terhadap struktur modal yang berarti sesuai dengan hipotesis pertama dimana profitabilitas berpengaruh negatif dan signifikan terhadap struktur modal. Hal ini berarti hipotesis 1 diterima.

H.2 : Semakin tinggi tingkat pertumbuhan aktiva akan menurunkan struktur modal.

Hasil pengujian hipotesis kedua menunjukkan bahwa hubungan variabel Tingkat pertumbuhan aktiva (X2) dengan struktur modal (Y1) menunjukkan nilai koefisien jalur sebesar -0,128 dengan nilai $t$ hitung sebesar 1,173. Nilai t hitung tersebut lebih kecil dari t tabel $(1,960)$. Hasil ini berarti bahwa tingkat pertumbuhan aktiva memiliki pengaruh yang negatif dan tidak signifikan terhadap struktur modal yang berarti tidak sesuai dengan hipotesis kedua dimana tingkat pertumbuhan aktiva berpengaruh signifikan terhadap struktur modal. Hal ini berarti hipotesis 2 ditolak.

H.3 : Semakin besar operating leverage akan menurunkan struktur modal. Hasil pengujian hipotesis ketiga menunjukkan bahwa hubungan

24| IQTISHODUNA Vol. 16 (1), 2020

http://ejournal.uin-malang.ac.id/index.php/ekonomi 
variabel operating leverage (X3) dengan struktur modal (Y1) menunjukkan nilai koefisien jalur sebesar 0,004 dengan nilai t hitung sebesar 0,9587. Nilai $t$ hitung tersebut lebih kecil dari t tabel $(1,960)$. hasil ini berarti bahwa operating leverage memiliki pengaruh yang positif dan tidak signifikan terhadap struktur modal yang berarti sesuai dengan hipotesis ketiga dimana operating leverage berpengaruh signifikan terhadap struktur modal. Hal ini berarti hipotesis 3 ditolak.

H.4 : Semakin tinggi stabilitas penjualan akan meningkatkan struktur modal.

Hasil pengujian hipotesis keempat menunjukkan bahwa hubungan variabel stabilitas penjualan (X4) dengan struktur modal (Y1) menunjukkan nilai koefisien jalur sebesar 0,223 dengan nilai t hitung sebesar 3,116. Nilai t hitung tersebut lebih besar dari t tabel $(1,960)$. Hasil ini berarti bahwa stabilitas penjualan memiliki pengaruh yang positif dan signifikan terhadap struktur modal yang berarti sesuai dengan hipotesis keempat dimana stabilitas penjualan berpengaruh signifikan terhadap struktur modal. Hal ini berarti hipotesis 4 diterima.

H.5 : Semakin tinggi profitabilitas akan meningkatkan nilai perusahaan.

Hasil pengujian hipotesis kelima menunjukkan bahwa hubungan variabel profitabilitas (X1) dengan nilai perusahaan (Y) menunjukkan nilai koefisien jalur sebesar 0,192 dengan nilai t sebesar 2,180. Nilai t hitung tersebut lebih besar dari t tabel $(1,960)$. Hasil ini berarti bahwa profitabilitas memiliki pengaruh yang positif dan signifikan terhadap nilai perusahaan yang berarti sesuai dengan hipotesis kelima dimana profitabilitas berpengaruh signifikan terhadap nilai perusahaan. Hal ini berarti hipotesis 5 diterima.

H.6 : Semakin tinggi tingkat pertumbuhan aktiva akan meningkatkan nilai perusahaan.

Hasil pengujian hipotesis keenam menunjukkan bahwa hubungan variabel tingkat pertumbuhan aktiva (X2) dengan nilai perusahaan (Y) menunjukkan nilai koefisien jalur sebesar 0,193 dengan nilai t hitung sebesar 2,351 . Nilai t hitung tersebut lebih besar dari t tabel $(1,960)$. Hasil ini berarti bahwa tingkat pertumbuhan aktiva memiliki pengaruh yang positif dan signifikan terhadap nilai perusahaan yang berarti sesuai dengan hipotesis keenam dimana tingkat pertumbuhan aktiva berpengaruh signifikan terhadap nilai perusahaan. Hal ini berarti hipotesis 6 diterima. 
H.7 : Semakin besar operating leverage akan menurunkan nilai perusahaan.

Hasil pengujian hipotesis ketujuh menunjukkan bahwa hubungan variabel operating leverage (X3) dengan nilai perusahaan (Y1) menunjukkan nilai koefisien jalur sebesar 0,110 dengan nilai t hitung sebesar 1,135. Nilai $t$ hitung tersebut lebih kecil dari t tabel $(1,960)$. hasil ini berarti bahwa operating leverage memiliki pengaruh yang positif dan tidak signifikan terhadap nilai perusahaan yang berarti tidak sesuai dengan hipotesis ketujuh dimana operating leverage berpengaruh signifikan terhadap nilai perusahaan. Hal ini berarti hipotesis 7 ditolak.

H.8: Semakin tinggi stabilitas penjualan akan meningkatkan nilai perusahaan.

Hasil pengujian hipotesis keempat menunjukkan bahwa hubungan variabel stabilitas penjualan (X4) dengan nilai perusahaan (Y1) menunjukkan nilai koefisien jalur sebesar 0,165 dengan nilai t hitung sebesar 2,036. Nilai $t$ hitung tersebut lebih besar dari t tabel $(1,960)$. Hasil ini berarti bahwa stabilitas penjualan memiliki pengaruh yang positif dan signifikan terhadap nilai perusahaan yang berarti tidak sesuai dengan hipotesis kedelapaan dimana stabilitas penjualan berpengaruh signifikan terhadap nilai perusahaan. Hal ini berarti hipotesis 8 ditolak.

H.9 : Semakin rendah struktur modal akan meningkatkan nilai perusahaan.

Hasil pengujian hipotesis kesembilan menunjukkan bahwa hubungan variabel struktur modal $(\mathrm{Z})$ dengan nilai perusahaan $(\mathrm{Y})$ menunjukkan nilai koefisien jalur sebesar -0,258 dengan nilai t hitung sebesar 3,430. Nilai $t$ hitung tersebut lebih besar dari t tabel $(1,960)$. Hasil ini berarti bahwa struktur modal memiliki pengaruh yang negatif dan signifikan terhadap nilai perusahaan yang berarti sesuai dengan hipotesis kesembilan dimana struktur modal berpengaruh signifikan terhadap nilai perusahaan. Hal ini berarti hipotesis 9 diterima.

H.10 : Semakin tinggi profitabilitas akan meningkatkan nilai perusahaan melalui struktur modal

Hasil pengujian hipotesis kesepuluh menunjukkan bahwa hubungan variabel profitabilitas (X1) dengan nilai perusahaan (Y2) melalui struktur modal menunjukkan nilai koefisien jalur sebesar 0,0694 dengan nilai $t$ sebesar 1,989. Nilai t hitung tersebut lebih besar dari t tabel $(1,960)$. Hasil ini berarti bahwa profitabilitas memiliki pengaruh yang positif dan signifikan terhadap nilai perusahaan yang melalui struktur modal. Hal ini berarti 
hipotesis 10 diterima.

H.11 : Semakin tinggi tingkat pertumbuhan aktiva akan meningkatkan nilai perusahaan melalui struktur modal

Hasil pengujian hipotesis kesebelas menunjukkan bahwa hubungan variabel tingkat pertumbuhan aktiva (X2) dengan nilai perusahaan (Y2) melalui Struktur Modal menunjukkan nilai koefisien jalur sebesar 0,0331 dengan nilai t sebesar 1,3826. Nilai t hitung tersebut lebih kecil dari t tabel $(1,960)$. Hasil ini berarti bahwa tingkat pertumbuhan aktiva memiliki pengaruh yang positif dan tidak signifikan terhadap nilai perusahaan yang melalui struktur modal. Hal ini berarti hipotesis 11 ditolak.

H.12 : Semakin besar operating leverage akan menurunkan nilai perusahaan melalui struktur modal.

Hasil pengujian hipotesis keduabelas menunjukkan bahwa hubungan variabel operating leverage (X3) dengan nilai perusahaan (Y) melalui struktur modal menunjukkan nilai koefisien jalur sebesar -0,0011 dengan nilai t sebesar $-0,0572$. Nilai t hitung tersebut lebih kecil dari t tabel $(1,960)$. Hasil ini berarti bahwa operating leverage memiliki pengaruh yang positif dan tidak signifikan terhadap nilai perusahaan yang melalui struktur modal. Hal ini berarti hipotesis 12 ditolak.

H.13 : Semakin tinggi stabilitas penjualan akan meningkatkan nilai perusahaan melalui struktur modal.

Hasil pengujian hipotesis ketiga belas menunjukkan bahwa hubungan variabel stabilitas penjualan (X4) dengan nilai perusahaan (Y) melalui struktur modal menunjukkan nilai koefisien jalur sebesar 0,0575 dengan nilai t sebesar $-2,2897$. Nilai t hitung tersebut lebih kecil dari t tabel $(1,960)$. Hasil ini berarti bahwa stabilitas penjualan memiliki pengaruh yang negatif dan signifikan terhadap nilai perusahaan yang melalui struktur modal. Hal ini berarti hipotesis 13 diterima. 


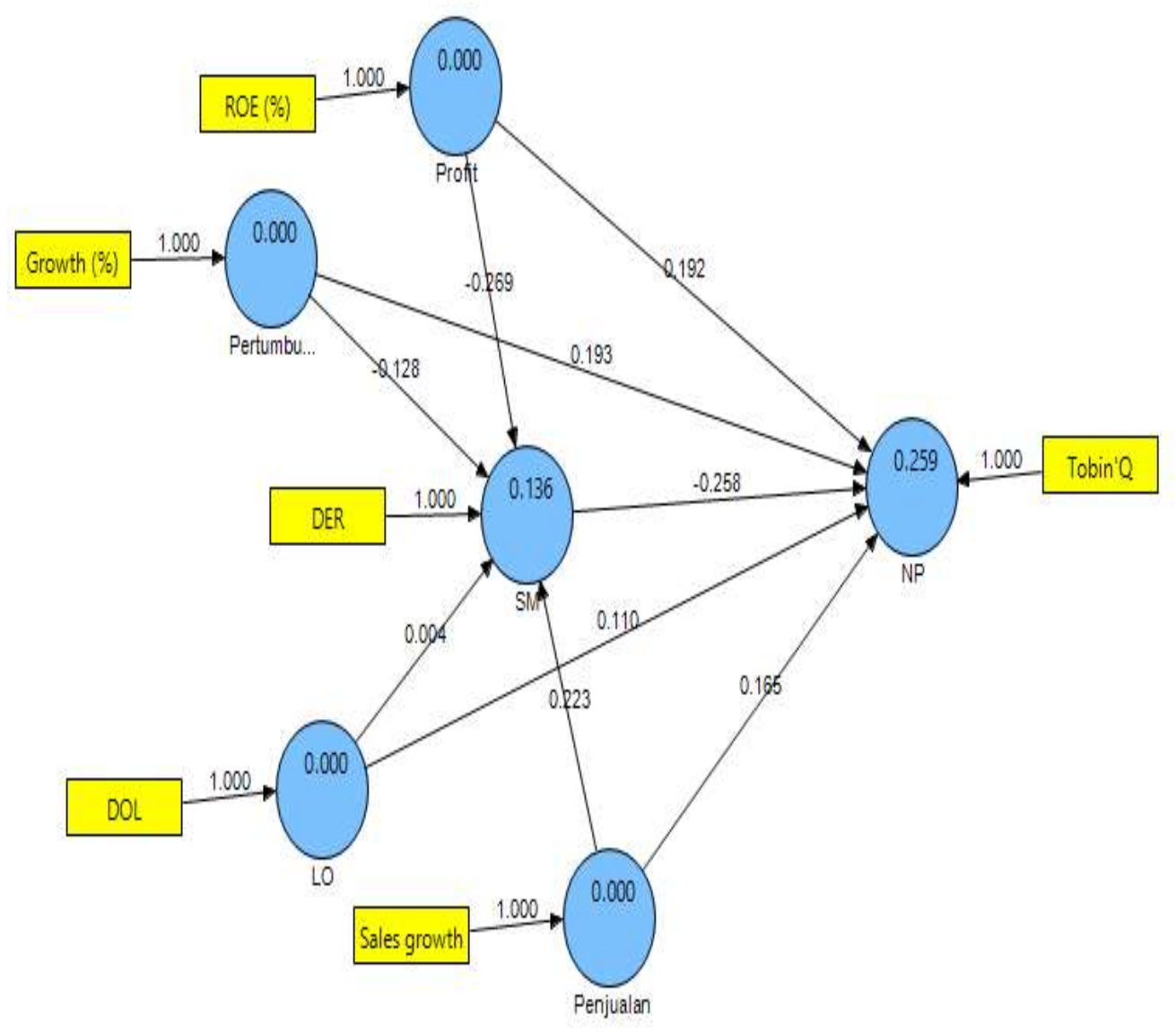

Gambar 2. Hasil Analisis PLS

Tabel 1. Statistik Deskriptif

\begin{tabular}{cccccc}
\hline & N & Minimum & Maximum & Mean & Std. Deviation \\
\hline ROE (\%) & 138 & -42.870 & 135.850 & 17.522 & 23.836 \\
Growth (\%) & 138 & -10.460 & 103.050 & 14.871 & 16.623 \\
DOL & 138 & -21.306 & 495.566 & 12.633 & 55.377 \\
Sales growth & 138 & -24.450 & 54.010 & 6.857 & 12.271 \\
DER & 138 & 0.080 & 4.151 & 0.828 & 0.706 \\
Tobin'Q & 138 & 0.288 & 130.751 & 8.553 & 18.068 \\
\hline
\end{tabular}


Pengaruh Profitabilitas, Tingkat Pertumbuhan...

Tabel 2. Hasil Analisis Pengujian Hipotesis Secara Langsung

\begin{tabular}{|c|c|c|c|c|c|}
\hline Variabel & $\begin{array}{c}\text { Original } \\
\text { Sample } \\
(0)\end{array}$ & $\begin{array}{c}\text { Standard } \\
\text { Deviation } \\
\text { (STDEV) }\end{array}$ & $\begin{array}{c}\text { T Statistics } \\
(\mid 0 / \text { STERR } \mid)\end{array}$ & p-value & Ket \\
\hline Profitabilitas -> SM & -0.269 & 0.108 & 2.498 & 0.0137 & Signifikan \\
\hline Pertumbuhan $->$ SM & -0.128 & 0.109 & 1.173 & 0.2428 & $\begin{array}{c}\text { Tidak } \\
\text { Signifikan }\end{array}$ \\
\hline $\mathrm{OL}->\mathrm{SM}$ & 0.004 & 0.083 & 0.052 & 0.9587 & $\begin{array}{c}\text { Tidak } \\
\text { Signifikan }\end{array}$ \\
\hline Penjualan -> SM & 0.223 & 0.072 & 3.116 & 0.0022 & Signifikan \\
\hline Profitabilitas $->\mathrm{NP}$ & 0.192 & 0.088 & 2.180 & 0.0310 & Signifikan \\
\hline Pertumbuhan $->$ NP & 0.193 & 0.082 & 2.351 & 0.0202 & Signifikan \\
\hline $\mathrm{OL}->\mathrm{NP}$ & 0.110 & 0.097 & 1.135 & 0.2585 & $\begin{array}{c}\text { Tidak } \\
\text { Signifikan }\end{array}$ \\
\hline Penjualan -> NP & 0.165 & 0.081 & 2.036 & 0.0438 & Signifikan \\
\hline $\mathrm{SM}->\mathrm{NP}$ & -0.258 & 0.075 & 3.430 & 0.0008 & Signifikan \\
\hline
\end{tabular}

Tabel 3. Hasil Analisis Pengujian Hipotesis Secara Tidak Langsung

\begin{tabular}{|c|c|c|c|c|c|c|c|c|c|}
\hline \multirow{2}{*}{$\begin{array}{l}\text { Variabel } \\
X_{1} \rightarrow Z \rightarrow Y\end{array}$} & \multicolumn{2}{|c|}{$\begin{array}{l}\text { Koefisien } \\
\text { Langsung }\end{array}$} & \multicolumn{3}{|r|}{$\begin{array}{c}\text { Koefisi } \\
\text { en } \\
\text { Tidak } \\
\text { Lang } \\
\text { sung } \\
\end{array}$} & \multirow{2}{*}{$\begin{array}{c}\begin{array}{c}\text { se } \\
\text { Sobel }\end{array} \\
0.0349\end{array}$} & \multirow{2}{*}{$\begin{array}{c}\begin{array}{c}\mathbf{t} \\
\text { Hitung }\end{array} \\
1.9898\end{array}$} & \multirow{2}{*}{$\begin{array}{c}\mathbf{p} \\
0.049\end{array}$} & \multirow{2}{*}{$\begin{array}{r}\text { Ket } \\
\text { Sig }\end{array}$} \\
\hline & -0.269 & -0.258 & 0.108 & 0.075 & 0.0694 & & & & \\
\hline$X_{2} \rightarrow Z \rightarrow Y$ & -0.128 & -0.258 & 0.109 & 0.075 & 0.0331 & 0.0239 & 1.3826 & 0.169 & $\begin{array}{c}\text { sig } \\
\text { Tidak }\end{array}$ \\
\hline $\mathrm{X}_{3} \rightarrow \mathrm{Z}-\rightarrow \mathrm{Y}$ & 0.004 & -0.258 & 0.083 & 0.075 & -0.0011 & 0.0194 & -0.0572 & 0.954 & sig \\
\hline $\mathrm{X}_{4} \rightarrow \mathrm{Z} \rightarrow \mathrm{Y}$ & 0.223 & -0.258 & 0.072 & 0.075 & -0.0575 & 0.0251 & -2.2897 & 0.024 & Sig \\
\hline
\end{tabular}

\section{Pembahasan}

\section{Pengaruh Profitabilitas Terhadap Struktur Modal}

Hasil penelitian dari perusahaan manufaktur ini menunjukkan bahwa pengaruh profitabilitas terhadap struktur modal adalah negatif dan signifikan. Hasil penelitian tersebut sesuai dengan pernyataan Brigham dan Houston (2006), tingginya tingkat pengembalian perusahaan atas investasi berdampak pada penggunaan utang yang relatif kecil dan memunginkan perusahaan untuk membiayai sebagian besar kebutuhannya dengan dana internal. Perusahaan yang memiliki profitabilitas tinggi biasanya memiliki sumber dana internal berlebih sehingga penggunaan utang secara berlebihan tidak diperlukan. Hasil penelitian yang dilakukan oleh Kesuma (2009) juga 
menunjukkan hasil yang sama, profitabilitas berpengaruh negatif terhadap struktur modal perusahaan. Semakin tinggi keuntungan yang diperoleh berarti semakin rendah kebutuhan dana eksternal (hutang) sehingga semakin rendah pula struktur modalnya.

\section{Pengaruh Tingkat Pertumbuhan Aktiva Terhadap Struktur Modal}

Hasil penelitian dari perusahaan manufaktur ini menunjukkan bahwa tingkat pertumbuhan aktiva memiliki pengaruh yang negatif dan tidak signifikan terhadap struktur modal. Perusahaan dengan tingkat pertumbuhan aktiva tinggi cenderung membelanjai pengeluaran investasi dengan modal sendiri untuk menghindari masalah underinvestment yaitu tidak dilaksanakannya semua proyek investasi yang bernilai positif oleh pihak manajer perusahaan (Chen, 2004). Selain itu, kebijakan hutang dan struktur kepemilikan modal juga dapat mempengaruhi nilai perusahaan dengan adanya pajak, biaya keagenan, dan biaya kesulitan keuangan sebagai imbangan dari manfaat penggunaan hutang. Sebaliknya, apabila perusahaan memperkirakan akan mengalami pertumbuhan yang rendah, mereka akan berupaya membagi risiko pertumbuhan rendah dengan para kreditur melalui penerbitan utang yang umumnya dalam bentuk utang jangka panjang (Mai, 2006).

\section{Pengaruh Operating Leverage terhadap Struktur Modal}

Hasil penelitian menunjukkan bahwa operating leverage berpengaruh positif dan tidak signifikan terhadap struktur modal. Semakin tinggi beban operasional yang dihasilkan perusahaan, maka perusahaan membutuhkan lebih banyak dana untuk membiayai operasinya yang bisa diperoleh dengan dana eksternal (hutang). Hal tersebut sesuai dengan pernyataan Brigham dan Houston (2006), perusahaan dengan operating leverage yang lebih sedikit memiliki kemampuan yang lebih baik dalam menerapkan leverage keuangan karena perusahaan tersebut akan memiliki risiko bisnis yang lebih kecil. Hasil penelitian ini sesuai dengan hasil penelitian yang dilakukan oleh Wulandari (2013) menyatakan bahwa operating leverage berpengaruh positif terhadap sruktur modal. Hal tersebut dikarenakan tingkat operating leverage yang tinggi berarti perusahaan mempunyai biaya tetap yang tinggi pula.

\section{Pengaruh Stabilitas Penjualan terhadap Struktur Modal}

Hasil penelitian menunjukkan bahwa stabilitas penjualan memiliki pengaruh yang positif dan signifikan terhadap struktur modal. Sebuah perusahaan yang penjualannya relatif stabil dapat dengan aman mengambil lebih banyak hutang dan menanggung beban tetap yang lebih tinggi daripada perusahaan dengan penjualan yang tidak stabil. Contohnya perusahaanperusahaan fasilitas umum, karena permintaan mereka yang stabil, secara 
historis dapat menggunakan lebih banyak leverage keuangan daripada perusahaan-perusahaan industri (Brigham dan Houston, 2006). Hal tersebut sesuai dengan penelitian yang dilakukan oleh Mawikere dan Paulina (2015) menemukan bahwa stabilitas penjualan berpengaruh signifikan terhadap struktur modal. Hal ini mengindikasikan apabila stabilitas penjualan dan laba bersih perusahaan sama-sama memiliki keadaan yang baik atau meningkat maka perusahaan akan lebih aman untuk mendapatkan pinjaman.

\section{Pengaruh Profitabilitas terhadap Nilai Perusahaan}

Hasil penelitian menunjukkan bahwa Profitabilitas memiliki pengaruh yang positif dan signifikan terhadap Nilai Perusahaan. Menurut Kasmir (2010) profitabilitas merupakan faktor yang dapat mempengaruhi nilai perusahaan. Jika manajer mampu mengelola perusahaan dengan baik maka biaya yang akan dikeluarkan oleh perusahaan akan menjadi lebih kecil sehingga laba yang dihasilkan menjadi lebih besar. Besar atau kecilnya laba ini yang akan mempengaruhi nilai perusahaan. hal tersebut sesuai dengan penelitian yang dilakukan oleh Wulandari (2013), Kesuma (2009), Dewi dan Ary (2013) menghasilkan bahwa profitabilitas berpengaruh positif dan signifikan terhadap nilai perusahaan.

\section{Pengaruh Tingkat Pertumbuhan Aktiva terhadap Nilai Perusahaan}

Hasil penelitian menyatakan bahwa tingkat pertumbuhan aktiva memiliki pengaruh yang positif dan signifikan terhadap nilai perusahaan. Semakin besar tingkat pertumbuhan aktiva akan mengindikasikan bahwa perusahaan tersebut memiliki total aset yang semakin meningkat, oleh karena itu akan memberikan sinyal yang positif terhadap para investor untuk menanamkan sahamnya di perusahaan tersebut. Hal tersebut tentu saja dapat meningkatkan harga saham dan tentu saja akan menaikkan nilai perusahaan. hal tersebut sesuai dengan penelitian yang dilakukan oleh Hasbi (2015) dan Hermuningsih (2013), Kusumajaya (2011), tingkat pertumbuhan aktiva mempunyai pengaruh positif dan signifikan terhadap nilai perusahaan.

\section{Pengaruh Operating leverage terhadap Nilai Perusahaan}

Operating Leverage memiliki pengaruh yang positif dan tidak signifikan terhadap Nilai Perusahaan. Operating leverage berhubungan dengan beban tetap, semakin besar beban tetap, maka semakin kecil keuntungan yang diperoleh oleh perusahaan. Rendahnya keuntungan yang diperoleh perusahaan akan berimbas pada penilaian prospek perusahaan. Keuntungan yang rendah tentu akan menyebabkan menurunnya nilai perusahaan terkait investor pasti lebih memilih perusahaan yang memiliki nilai keuntungan yang tinggi. Penelitian yang sejalan dengan hasil penelitian ini telah dilakukan oleh Putra (2013) yang menemukan bahwa operating leverage 
(DOL) tidak berpengaruh terhadap EPS.

\section{Pengaruh Stabilitas Penjualan terhadap Nilai Perusahaan}

Hasil penelitian menunjukkan bahwa stabilitas penjualan memiliki pengaruh yang positif dan signifikan terhadap nilai perusahaan. Pertumbuhan penjualan akan memberikan sinyal positif kepada investor bahwa perusahaan memiliki prospek perusahaan yang bagus dan pada akhirnya dapat meningkatkan nilai perusahaan. Perusahaan yang memiliki pertumbuhan penjualan yang tinggi dipandang memiliki kesiapan untuk bersaing dan diiringi adanya peningkatan pangsa pasar yang secara langsung menaikkan nilai perusahaan (Safrida, 2008). Penelitian ini sejalan dengan penelitian yang dilakukan oleh Kusumajaya (2011). Hasil yang diperoleh dari penelitian tersebut adalah pertumbuhan penjualan mempunyai pengaruh yang positif dan signifikan terhadap nilai perusahaan.

\section{Pengaruh Struktur Modal terhadap Nilai Perusahaan}

Hasil penelitian menunjukkan bahwa struktur modal memiliki pengaruh yang negatif dan signifikan terhadap nilai perusahaan. Kebijakan hutang merupakan instrumen yang sangat sensitif terhadap nilai perusahaan. Semakin tinggi proporsi hutang, maka semakin tinggi harga saham, namun pada titik tertentu peningkatan hutang akan menurunkan nilai perusahaan karena manfaat yang diperoleh dari penggunaan hutang lebih kecil dari pada biaya yang ditimbulkannya. Para pemilik perusahaan lebih suka jika perusahaan menciptakan hutang pada tingkat tertentu untuk menaikkan nilai perusahaan (Nuraina, 2012). Hasil penelitian ini sama dengan penelitian yang pernah dilakukan oleh Hoque et al. (2014) menunjukkan hasil temuan bahwa struktur modal cenderung memiliki dampak negatif terhadap nilai perusahaan. Kemudian Fumani dan Abdolkarim (2015) menunjukkan adanya hubungan yang tidak signifikan antara leverage dan nilai pasar. Sedangkan Aggarwal dan Padhan (2017) telah menemukan bahwa leverage mempunyai hubungan positif signifikan dengan nilai perusahaan.

\section{Pengaruh Profitabilitas terhadap Nilai Perusahaan melalui Struktur Modal}

Hasil penelitian menunjukkan bahwa profitabilitas memiliki pengaruh yang positif dan signifikan terhadap nilai perusahaan yang melalui struktur modal. Menurut Brigham dan Houston (2006), tingginya tingkat pengembalian perusahaan atas investasi berdampak pada penggunaan utang yang relatif kecil dan memunginkan perusahaan untuk membiayai sebagian besar kebutuhannya dengan dana internal. Perusahaan yang memiliki profitabilitas tinggi biasanya memiliki sumber dana internal berlebih sehingga penggunaan utang secara berlebihan tidak diperlukan. Semakin 
kecil hutang yang digunakan maka semakin kecil pula risiko yang ditanggung oleh perusahaan, sehingga dapat meningkatkan persepsi positif bagi para investor dan tentu saja meningkatkan nilai perusahaan. Hasil penelitian ini sejalan dengan penelitian yang dilakukan oleh Wulandari (2013). Hasil menunjukkan bahwa profitabilitas berpengaruh terhadap nilai perusahaan dan terhadap struktur modal sebagai intervening.

\section{Pengaruh Tingkat Pertumbuhan Aktiva terhadap Nilai Perusahaan melalui Struktur Modal}

Hasil penelitian menunjukkan bahwa tingkat pertumbuhan aktiva memiliki pengaruh yang positif dan tidak signifikan terhadap nilai perusahaan yang melalui struktur modal. Perusahaan dengan tingkat pertumbuhan aktiva yang tinggi sebaiknya menggunakan ekuitas sebagai sumber pembiayaan untuk menghindari biaya keagenan (agency cost) antara pemegang saham dengan manajemen perusahaan. Sebaliknya, perusahaan dengan tingkat pertumbuhan aktiva yang rendah sebaiknya menggunakan hutang sebagai sumber pembiayaannya karena penggunaan hutang mengharuskan perusahaan tersebut membayar bunga secara teratur. Kedua hal tersebut sama-sama bertujuan untuk memperoleh laba semaksimal mungkin. Semakin tinggi kemampuan perusahaan untuk memperoleh laba, maka semakin besar return yang diharapkan oleh para investor. Oleh karena itu perusahaan yang memiliki pertumbuhan tinggi akan diminati sahamnya oleh para investor. Penelitian terdahulu yang sejalan telah dilakukan oleh Safrida (2008) menemukan hubungan yang positif antara profitabilitas dan nilai perusahaan pada perusahaan.

\section{Pengaruh Operating Leverage terhadap Nilai Perusahaan melalui Struktur Modal}

Hasil penelitian menunjukkan bahwa operating leverage memiliki pengaruh yang positif dan tidak signifikan terhadap nilai perusahaan yang melalui struktur modal. Operating leverage berhubungan dengan biaya tetap, apabila operating leverage perusahaan tinggi perusahaan cenderung akan mengurangi struktur modal guna memperkecil beban yang harus dikeluarkan. Semakin besar beban tetap, maka semakin kecil keuntungan yang didapat oleh perusahaan. Rendahnya keuntungan yang didapat perusahaan ini berimbas pada penilaian prospek perusahaan, keuntungan yang kecil akan menyebabkan rendahnya nilai perusahaan (Wulandari, 2013). Hasil penelitian ini sejalan dengan penelitian yang dilakukan oleh Putra (2013) menemukan bahwa operating leverage (DOL) tidak berpengaruh terhadap EPS. Namun berbeda dengan penelitian yang dilakukan oleh Wulandari (2013) menemukan bahwa operating leverage 
berpengaruh terhadap nilai perusahaan dan terhadap struktur modal sebagai intervening.

\section{Pengaruh Stabilitas Penjualan terhadap Nilai Perusahaan melalui Struktur Modal}

Hasil penelitian menunjukkan bahwa stabilitas penjualan memiliki pengaruh yang negatif dan signifikan terhadap nilai perusahaan yang melalui struktur modal. Menurut Mahapsari dan Abdullah (2013) peningkatan penjualan dapat meningkatkan kemampuan perusahaan untuk memperoleh pendapatan dan laba perusahaan, dengan peningkatan penjualan tersebut, maka perusahaan dapat menutup biaya-biaya yang dikeluarkan untuk operasional perusahaan, dan memperbaiki struktur modal perusahaan karena perusahaan dapat membayar hutangnya dan dapat meningkatkan modal sendiri. Jadi, risiko perusahaan tidak bisa membayar bebannya juga kecil. Oleh sebab itu, investor juga akan melihat bahwa perusahaan mampu untuk menutupi hutang dan meningkatkan modalnya. Hal ini tentu akan direspon positif oleh pasar.

\section{Kesimpulan}

Berdasarkan permasalahan yang telah dirumuskan, hasil analisis dan pengujian hipotesis yang telah dilakukan, maka dapat diambil kesimpulan bahwa Laba yang dihasilkan perusahaan mengurangi jumlah pengambilan hutang suatu perusahaan. Apabila laba yang dihasilkan perusahaan cukup besar, maka perusahaan cenderung menggunakan laba ditahan untuk membiayai operasionalnya sehingga tidak membutuhkan hutang yang banyak. Meningkatnya pertumbuhan aktiva dari tahun ke tahun tidak mendorong keputusan penggunaan hutang. Sebagian besar perusahaan menggunakan saham dalam mendanai operasionalnya daripada menggunakan aktiva.

Leverage operasi tidak mempengaruhi keputusan penggunaan hutang. EBIT yang tinggi berarti bahwa resiko tinggi sehingga perusahaan meminimalisir dengan tidak menggunakan hutang, melainkan modal sendiri. Stabilitas penjualan mendorong perusahaan dalam pengambilan hutang. Stabilitas penjualan memperkecil resiko perusahaan tidak dapat membayar hutangnya, sehingga perusahaan lebih aman dalam pengambilan hutang.

Profitabilitas dapat meningkatkan nilai perusahaan karena mempengaruhi persepsi investor terhadap perusahaan bahwa perusahaan tersebut memiliki kinerja yang baik sehingga dapat meningkatkan nilai perusahaan. Tingkat pertumbuhan aktiva dapat meningkatkan nilai perusahaan, dikarenakan tingkat pertumbuhan aktiva suatu perusahaan

34| IQTISHODUNA Vol. 16 (1), 2020

http://ejournal.uin-malang.ac.id/index.php/ekonomi 
mencerminkan bahwa perusahaan tersebut semakin baik sehingga dapat meningkatkan nilai sebuah perusahaan.

Leverage operasi tidak mencerminkan nilai sebuah perusahaan. Hal tersebut dikarenakan jumlah beban yang dimiliki perusahaan tidak mencerminkan bahwa perusahaan tersebut memiliki nilai perusahaan yang baik atau tidak baik, tetapi tergantung bagaimana perusahaan tersebut dapat memenuhi beban operasionalnya. Stabilitas penjualan mencerminkan bagaimana nilai perusahaan. Penjualan yang stabil menunjukkan bahwa perusahaan memiliki peningkatan pendapatan yang stabil juga dan tentunya meningkatkan nilai perusahaan.

Struktur modal berkontribusi dalam baik buruknya nilai perusahaan, yang berarti bahwa pengambilan keputusan hutang mempengaruhi nilai dari sebuah perusahaan. Besarnya hutang yang dimiliki perusahaan meningkatkan resiko yang dimiliki oleh perusahaan yang tentunya dapat menurunkan nilai dari perusahaan. Meningkatnya laba yang dihasilkan perusahaan menurunkan penggunaan hutang, sedikitnya hutang berarti resiko yang ditanggung perusahaan juga kecil. Hal tersebut tentunya meningkatkan nilai perusahaan karena dinilai investor baik.

Tingkat pertumbuhan aktiva tidak mencerminkan nilai perusahaan melalui struktur modal, karena besar kecilnya aktiva tidak mempengaruhi keputusan dalam penggunaan hutang dan tentunya tidak mempengaruhi nilai perusahaan. Leverage operasi tidak mencerminkan nilai perusahaan melalui struktur modal, karena besarnya beban yang ditanggung dari kegiatan operasional tidak mengharuskan perusahaan mengambil hutang apabila bisa didanai dari dana internal sehingga tentunya beban operasional juga tidak mempengaruhi nilai perusahaan melalui struktur modal. Stabilitas penjualan meningkatkan nilai perusahaan melalui struktur modal. Penjualan yang stabil dapat dengan aman mengambil hutang, tingginya hutang menurunkan nilai perusahaan terkait besarnya resiko yang ditanggung.

\section{Daftar Pustaka}

Anggarwal dan Padhan. (2017). Impact of Capital Structure on Firm Value: Evidence from Indian Hospitality Industry. Theoretical Economics Letters. $\quad$ Pp. 982-1000. ISSN online: 2162-2086. http://www.scirp.org/journal/tel.

Brealey, M., Marcus. (2008). Dasar-dasar Manajemen Keuangan. Jakarta: Erlangga.

Brigham, E.F., Houston, J.F. (2001). Manajemen Keuangan. Edisi Kedelapan Buku Dua. Jakarta: Erlangga. 
Brigham, E. F., Houston, J.F. (2006). Manajemen Keuangan. Buku II. Edisi ke Delapan. Jakarta: Erlangga.

Chen, L. Y. (2004). Examining The Effect of Organization Culture and Leadership Behaviors on Organizational Commitment, Job Satisfaction, Job Performance at Small And Middle-Sized Firma of Taiwan. Journal of American Academy of Business. Vol 5(2). Pp: 432-438.

Dewi, A.S.M., Ary, W. (2013). Pengaruh Struktur Modal, Profitabilitas dan Ukuran Perusahaan terhadap Perusahaan. E- Journal Akuntansi Universitas Udayana. Vo; 4(2). Pp: 358-372.

Ermad M.J. (2012). Pengaruh Tangibility, Pertumbuhan Penjualan, Profitabilitas, dan Kepemilikan Institusional terhadap Struktur Modal pada Perusahaan Industri Dasar dan Kimia yang terdaftar di Bursa Efek Indonesia. Tesis. Program Studi Magister Akuntansi Program Pasca Sarjana Universitas Syiah Kuala.

Fumani, M.A., Abdolkarim, M. (2015). The Effect of Capital Structure on Firm Value, The Rate of Return on Equity and Earnings Per Share of Listed Companies in Tehran Stock Exchange. Research Journal of Finance and Accounting. Vol. 6(15). Pp: 51-58.

Hasbi, H. (2015). Islamic Microfinance Institution: The Capital Structure, Growth, Performance and Value of Firm in Indonesia. Procedia - Social and Behavioral 211: Sciences 1073-80. doi:10.1016/j.sbspro.2015.11.143.

Hermuningsih, S. (2013). Pengaruh Profitabilitas, Growth Opportunity, Struktur Modal Terhadap Nilai Perusahaan Pada Perusahaan Publik Indonesia. Buletin Ekonomi Moneter dan Perbankan. Edisi Oktober 2013.

Hoque, J., Ashraf, H., Kabir, H. (2014). Impact of Capital Structure Policy on Value of The Firm - A Study on Some Selected Corporate Manufacturing Firms Under Dhaka Stock Exchange. Ecoforum. Vol. 3(5): 77-84.

Husnan, S. (2008). Manajemen Keuangan : Teori dan Penerapan Buku 1, Edisi 4. Yogyakarta: BPFE.

Husnan, S. (2009). Teori Portofolio dan Analisis Sekuritas. Edisi Keempat. Yogyakarta: UPP STIM YKPN. .

Kasmir. (2010). Pengantar Manajemen Keuangan. Jakarta: Kencana Prenada Media Group.

Keown J. A., David, S.F. (2000). Dasar-Dasar Manajemen Keuangan. Jakarta: Salemba Empat.

Kesuma, A. (2009). Analisis Faktor yang Mempengaruhi Struktur Modal serta Pengaruhnya Terhadap Harga Saham Perusahaan Real Estate yang Go-

36| IQTISHODUNA Vol. 16 (1), 2020

http://ejournal.uin-malang.ac.id/index.php/ekonomi 
Public di BEI. Jurnal Manajemen \& Kewirausahaan. Vol.2(1). Pp: 3845.

Kusumajaya, D.K.O. (2011). Pengaruh Struktur Modal dan Pertumbuhan Perusahaan Terhadap Profitabilitas dan Nilai Perusahaan Pada Perusahaan Manufaktur di Bursa Efek Indonesia. Tesis. Denpasar: Universitas Udayana.

Mahapsari, N. R., Abdullah,T. (2013). Pengaruh Profitabilitas, Struktur Aktiva, Dan Pertumbuhan Penjualan Terhadap Harga Saham Dan Struktur Modal Sebagai Variabel Intervening Pada Perusahaan Manufaktur Di Bursa Efek Indonesia. Jurnal Nominal. Vol. 2(1).

Mai, M. U. (2006). Analisis Variabel-variabel yang Mempengaruhi Struktur Modal Pada Perusahaan-Perusahaan LQ-45 di Bursa Efek Jakarta. Ekonomika. Pp. 228-245.

Mawikere, C. Y., Paulina, V.R. (2015). Pengaruh Stabilitas Penjualan dan Struktur Aktiva terhadap Struktur Modal Perusahaan Automoive and Alled Product yang Terdaftar di BEI Periode 2010-2013. Jurnal EMBA. Vol.3. Pp: 149-158. ISSN: 2146-4138.

Modigliani, F \& Miller, M.H. (1958). The Cost of Capital, Corporation Finance and The Theory of Investment. The American Economic Review. 13(3). Pp: 261- 297.

Munawir. (2007). Analisis Laporan Keuangan, Edisi Empat. Yogyakarta: Liberty.

Niztiar, G. (2013). Analisis Faktor Yang Mempengaruhi Struktur Modal (Studi Kasus Pada Perusahaan Pertambangan Yang Terdaftar Di Bursa Efek Indonesia Periode 2008-2011). Skripsi. Fakultas Ekonomika Dan Bisnis Universitas Diponegoro. Diperoleh tanggal 24 Mei 2015.

Nuraina, E. (2012). Pengaruh Kepemilikan Institusioanal dan Ukuran Perusahaan terhadap Kebijakan Hutang dan Nilai Perusahaan (Studi pada perusahaan manufkatur yang terdaftar di BEI). AKRUAL 4(1). Pp: 510-70.

Putra, I.R. (2013). Analisis Pengaruh Operating Leverage dan Financial Leverage terhadap Earning per Share (EPS) di Perusahaan Properti yang Terdaftar di BEI (2007-2011). Jurnal Ilmu Manajemen. Vol.1(1). Januari 2013.

Rudianto. (2009). Akuntansi Manajemen. Yogyakarta: Grasindo

Sartono. A.R. (2010). Manajemen Keuangan Teori dan Aplikasi. Edisi Keempat. Yogyakarta: BPFE

Safrida, E. (2008). Pengaruh Struktur Modal dan Pertumbuhan Perusahaan terhadap Nilai Perusahaan pada Perusahaan Manufaktur di BEI. Tesis. 
Medan: Universitas Sumatera Utara

Seftianne dan Handayani. (2011). Faktor-Faktor yang Mempengaruhi Struktur Modal pada Perusahaan Publik Sektor Manufaktur. Jurnal Bisnis dan Akuntansi. Vol. 13(1). Pp: 39 - 56.

Sjahrial, D. (2009). Manajemen Keuangan. edisi 3. Jakarta: Mitra Wacana Media.

Sudana, I Made. (2011). Manajemen Keuangan Perusahaan, Teori dan Praktik. Jakarta: Erlangga.

Weston, J. F., Copeland, T.E. (2008). Manajemen Keuangan, Penerjemah: A. Jaka Wasana Jakarta: Binarupa Aksara.

Wulandari, D. R. (2013). Pengaruh Profitabilitas, Opertiang Leverage, dan Likuiditas terhadap Nilai Perusahaan dengan Struktur Modal sebagai Variabel Intervening. Accounting Analysis Journal. ISSN 2252-6765. 